\title{
ANAK, MINAT BACA, DAN MENDONGENG
}

\author{
I Ketut Artana \\ Pustakawan Utama Universitas Pendidikan Ganesha \\ Email:Bagasartana@gmail.com
}

\begin{abstract}
Children's reading interest today is not encouraging. Various facts and data on statistical reports related to reading interest and reading ability among children show that children's reading interest is still low. The role of parents or family or other parties are required to do or make a way of strategy for the interest of reading children can grow and develop well. One effort to foster interest in reading in children is to tell stories. Basically fairy tales contain positive values for life, because in it contained moral and ethical demands. Storytelling is one effort or technique to foster reading interest in children. Parents or other family members as well as other parties can act as speakers of the books they read and, of course, fairytale material adapted to the level of language development and age of the child. The storytelling activity will be more effective when delivered or told at bedtime, during the family relax time, or it can be given ahead of and after class lesson. If the activity is done well, continuously, will gradually arise the child's desire to read their own books. Therefore storytelling is one of the best ways to foster reading interest in children.
\end{abstract}

\section{Keywords: reading interest, storytelling, children}

\section{PENDAHULUAN}

Pesatnya perkembangan teknologi informasi yang ditandai dengan maraknya siaran televisi swasta nasional, permainan game, internet dan media hiburan lainnya, kian merebut perhatian masyarakat khususnya anak-anak. Kegiatan mendoneng yang dulu sering terdengar sekarang sudah jarang dilakukan oleh orang tua atau pihak-pihak lain kepada anak-anak.

Padahal, jika dikaji secara mendalam kegiatan mendongeng merupakan sarana untuk berkomunikasi dua arah (umumnya antara orang tua dan anak). Kegiatan ini juga merupakan metode yang sangat ampuh dalam menumbuhkembangkan daya nalar, rasa ingin tahu dan kreativitas anak serta merupakan suatu cara yang efektif untuk memperkenakan buku-buku (bahan bacaan) kepada anak-anak.

Seperti diketahui bahwa minat baca anak-anak untuk membaca saat ini kondisinya belumlah menggembirakan. Berdasarkan Kajian Organisasi 
Pendidikan, Ilmu Pengetahuan, dan Kebudayaan PBB (UNESCO), pada tahun 2012 mencatat indeks minat baca di Indonesia baru mencapai 0,001. Itu artinya, bahwa dalam setiap 1.000 orang, hanya ada satu orang yang punya minat membaca.

Berkaitan dengan kemampuan anak, data menunjukkan bahwa kemampuan anak Indonesia usia 15 tahun di bidang matematika, sains, dan membaca dibandingkan dengan anak-anak lain di dunia masih rendah. Hasil Programme for International Student Assessment (PISA) 2012, Indonesia berada di peringkat ke-64 dari 65 negara yang berpartisipasi dalam tes (Kompas, 5 Desember 2013). Sedangkan, UNDP merilis angka melek huruf orang dewasa Indonesia hanya 65,5 persen, sementara Malaysia sudah mencapai 86,4 persen.

Kondisi seperti itu tentunya menjadi perhatian kita semua. Saat ini pemerintah sedang berupaya keras meningkatkan kualitas sumber daya manusia agar mampu bersaing dengan negara-negara lain. Kepala Perpusnas Sri Sularsih mengatakan tingkat kesejahteraan masyarakat maju dilihat dari kualitas sumber daya manusianya, yang salah satunya bisa dicapai melalui kegemaran membaca. Kenapa membaca menjadi bagian dari standar kesejahteraaan hidup masyarakat karena didalam aktivitas tersebut masyarakat dipacu untuk memiliki kemampuan literasi yang baik. Jika kualitas literasi masyarakat sudah teruji, maka informasi dan ilmu pengetahuan bisa mudah terserap untuk diaplikasikan dalam segala bidang profesi, yang ujung-ujungnya kualitas sumber daya manusia meningkat dan otomatis berdampak pada kesejahteraan.

Upaya mewujudkan Indonesia Cerdas melalui Gemar Membaca secara runut disampaikan Kepala Perpusnas memuat enam misi besar, antara lain 1) mewujudkan koleksi nasional yang lengkap dan mutakhir; 2) diversifikasi layanan perpustakaan berbasis TIK terus dikembangkan; 3) pemanfaaatan perpustakaan terus diperluas jangkauan agar masyarakat lebih mudah menggunakan; 4) menciptakan tenaga perpustakaan yang berkompeten dan profesional; 5) intensitas dan kualitas sosialisasi, promosi, dan pemasyarakatan gemar membaca terus digalakkan; dan 6) mengembangkan infrastruktur Perpustakaan Nasional yang modern. Target- target yang dirumuskan Perpusnas tersebut sesuai ke dalam struktur pembangunan Nawa Cita era Presiden Jokowi hingga 2019. 
Untuk mampu mewujudkan itu semua pihak yang terlibat dalam pembudayaan gemar membaca khususnya pada anak-anak membuat suatu langkah agar anak-anak memiliki pemahaman betapa pentingnya membaca buku dalam era globalisasi ini. Salah satu upaya menumbuhkan minat baca pada anakanak adalah dengan mendongeng. Penumbuhan minat baca melalui dongeng merupakan peristiwa sosial dan kultural yang penting dalam kehidupan anak.

Bertolak pada paparan di atas, maka akan dibahas lebih mendalam tentang peran orangtua dan pemerintah dalam minat baca, dongeng dalam kehidupan anak dan peran mendongeng dalam menumbuhkan minat baca.

\section{PEMBAHASAN}

\section{Peranan Orangtua dan Pemerintah dalam Minat Baca Anak}

Saat ini minat baca di kalangan anak-anak masih rendah. Berbagai hasil kajian dan data statistic menunjukkan bahwa minat membaca anak belum menggembirakan. Hal ini tentunya menjadi perhatian semua baik pemerintah, orangtua anak, maupun pihak swasta serta tokoh-tokoh semua elemen menyatukan persepsi dan langkah yang aplikatif agar minat baca di kalangan anak-anak dapat tumbuh dengan baik. Hal ini mengingat bahwa anak-anak adalah calon generasi penerus yang akan mengisi dan melanjutkan pembangunan bangsa di masa yang akan datang.

Keluarga merupakan tempat pendidikan yang pertama dan utama bagi anak. Orangtua mempunyai peranan kunci dan penting bagi anak. Pendidikan dalam keluarga adalah untuk mengantarkan anak agar kelak dapat hidup mandiri sebagai pribadi dan warga masyarakat.Pendidikan dalam keluarga juga sangat menentukan dalam mengembangkan watak, kepribadian, nilai-nilai budaya, nilainilai keagamaan dan moral; serta keterampilan dalam kehidupan sehari-hari.

Tanggung jawab keluarga dalam pendidikan anak sangat besar. Hal ini mengingat sebagian besar waktu yang dimiliki oleh anak, sebelum mereka dapat berdiri sendiri berada di rumah bersama-sama orangtuanya. Keberhasilan anak dalam belajar di sekolah pun, akan ditentukan oleh peranan orangtua. Karena itu, pendidikan anak di sekolah harus selalu saling melengkapi dan saling mengisi pendidikan di rumah. 
Pengembangan minat baca yang baik secara teoritis harus dimulai sedini mungkin pada masa anak-anak. Di sini, keluarga terutama orangtua mempunyai peranan yang sangat menentukan dalam upaya mengembangkan perilaku gemar membaca pada diri anak-anak. Dalam hal ini, fungsi keluarga bukanlah sematamata hanya melakukan fungsi reproduksi atau fungsi perlindungan, akan tetapi juga bertanggung jawab melakukan fungsi social, termasuk di dalamnya mendidik dan mengarahkan anak agar memiliki jiwa gemar membaca.

Menumbukan minat baca sejak dini perlu didukung oleh lingkungan yang mendorong ke arah itu.Peranan orangtua dan keluarga, salah satunya dapat menunjang kegemaran membaca pada anak, karena salah satu hambatan belum tumbuhnya gemar membaca di kalangan anak-anak adalah peranan orangtua atau keluarga. Hal ini sejalan dengan hasil penelitian Juni Ambasari dalam Dantes (2016), menyimpulkan bahwa upaya mengembangkan literasi dasar anak usia dini masih mengalami banyak hambatan, salah satu hambatannya adalah peran orangtua yang dianggap kurang dalam menumbuhkan dan mengembangkan minat membaca dan menulis pada anak. Oleh karena pihak orang tua atau keluarga dapat mencari atau membuat cara atau upaya agar minat baca anak dapat tumbuh dan berkembang.Salah satu upaya itu adalah dengan mendongeng.

Selain orangtua, pemerintah juga dituntut peran sertanya dalam menumbuhkan minat baca masyarakat. Sesuai PP Nomor 24 tahun 2014 tentang Pelaksanaan UU No.43 tahun 2007 tentang perpustakaan, dinyatakan bahwa pembudayaan kegemaran membaca dapat dilakukan melalui: (1) gerakan nasional gemar membaca, (2) penyediaan buku murah dan berkualitas, (3) pengembangan dan pemanfaatan perpustakaan sebagai proses pembelajaran, (4) penyediaan sarana perpustakaan di tempat umum yang mudah dijangkau, murah, dan bermutu, (5) taman bacaan masyarakat, (6) rumah baca, dan atau (7) kegiatan sejenisnya.

\section{Dongeng dalam Kehidupan Anak}

Jika anak-anak ditanya, apakah pernah mendengar atau membaca dongeng? Barangkali hanya sedikit menjawab pernah dan selebihnya mengatakan jarang atau bahkan tidak pernah mendengar atau membaca sama sekali. Kondisi 
seperti itu tidak dapat dipungkiri dan memang harus diakui bahwa kegiatan mendongeng sudah mulai menurun dan tidak popular lagi di setiap keluarga, terutama pada keluarga yang tinggal di kota-kota atau pada keluarga yang memiliki kesibukan kerja amat padat.

Banyak faktor penyebabnya. Diantaranya yaitu keterbatasan waktu karena kesibukan orangtua dalam hal bekerja, kurangnya perbendaharaan materi atau bahan bacaan dongeng para orangtua, pengaruh kemajuan teknologi elektronik, dan atau karena perubahan social dan pola hidup masyarakat. Kondisi semacam ini akan semakin menjauhkan diri akan-anak pada dunia dongeng dalam kehidupannya. Padahal, bilamana dicermati lebih jauh sebenarnya banyak manfaat dongeng bagi kehidupan anak-anak.

Dongeng adalah media yang paling baik untuk mengajarkan bahasa dan literasi. Dongeng mengandung ungkapan bahasa yang eksploratif dan imajinatif, yang memungkinkan anak-anak berpikir, bercermin diri dan bertanya pada eksistensi dirinya, karena dongeng menyajikan keindahan dan renungan hidup. Dikatakan pula bahwa dongeng adalah kehidupan. Ia bercerita tentang kehidupan, merepleksikan kehidupan di masa lalu dan memproteksikan kehidupan di masa depan. Dongeng adalah sebuah media untuk pembelajaran karakter. Bahkan salah satu definisi dari cerita (fiksi) dalam Basuki (1988) menyebutkan bahwa cerita adalah sebuah karangan yang bercerita tentang karakter (tokoh). Jadi cerita dalam sastra adalah tentang seorang tokoh menghadapi persoalannya dan menyelesaikannya. Karakter disini adalah seseorang yang menghadapi kehidupan dan kompleksitasnya. Ia adalah subjek dalam cerita, sebagaimana manusia adalah subjek dalam kehidupan.

Dongeng juga dikatakan sebagai warisan nenek moyang secara turun temurun mesti dan patut dilestarikan. Mesikpun kebenarannya masih dipertanyakan, namun dongeng termasuk karya sastra yang mampu membangun karakteristik anak-anak sejak dini, dongeng juga merupakan salah satu cara yang efektif untuk mengembangkan aspek kognitif atau pengetahuan, afektif atau perasaan, social dan aspek konatif atau penghayatan, dapat membawa anak-anak pada pengalaman-pengalaman baru yang belum pernah dialaminya, memdapat hikmah untuk belajar sesuatu. Melalui dongeng anak tidak akan merasa digurui 
karena mereka merespon segala sesuatu dengan cara mereka sendiri, siswa akan memperoleh pelepasan emosional lewat pengalaman fiktif yang tidak pernah mereka alami dalam kehidupan nyata. Melalui metode bercerita ini pendongeng akan mampu menularkan pengetahuan dan menanamkan nilai moral dan budi pekerti secara efektif dan anak akan menerimanya dengan senang hati.

Menurut Lilian Holewell dalam "A Book for Children Literature" (dalam Artana, 1997), ada enam dongeng bagi anak-anak, yaitu (1) mengembangkan daya imajinasi dan pengalaman emosional, (2) memuaskan kebutuhan ekspresi dirinya melalui proses identifikasi, (3) pemberian pendidikan moral tanpa si anak digurui, (4) memperluas cakrawala mental si anak dan memberikan kesempatan untuk meresapi keindahan, (5) menumbuhkan rasa humor dalam diri anak, dan (6) memberikan persiapan apresiasi sastra dalam kehidupan anak setelah dia dewasa.

Menyimak bahwa dunia memang relevan dengan dunia khayalan (fantasi, hiburan), maka dongeng menjadi berperan dalam proses edukasi anak. Dengan kata lain, dongeng bias menjadi media ampuh untuk mengajarkan apapun pada anak-anak. Di sini dongeng secara anatomis dapat dibedakan dalam beberapa dimensi atau karakter. Karakter tersebut yaitu dongeng sebagai sarana hiburan, sarana pendidikan dan sarana sosialisasi. Ketika karakter dasar sebuah dongeng dipahami, dimengerti akan dapat menjadi dasar akomodatif anak.

Intensitas pengenalan dongeng, baik dari peran orangtua atau guru mamupun lewat media audio-visual dan media massa menjadi penting bagi proses pendidikan anak. Interaksi yang berdimensi konstruktif ini pada gilirannya akan membuat anak mampu memperkaya imajinasi dan cara berpikirnya untuk dapat merasakan kesedihan, kegembiraan, ketegangan, dan lain sebagainya. Kontinuitas pengenalan ini secara tidak langsung juga berkaiatan erat dengan kemampuan mendengarkan, menyimak, dan menafsirkan isi/tema dongeng untuk mencapai makna kehidupan yang relevan relative dengan psikologi anak.

Dongeng yang bertemakan pendidikan akan dapat menumbuhkan aspek kostruktif bagi anak. Anak-anak akan diperkenalkan kepada kebenaran, kebaikan, keluhuran, sekalhigus kelicikan, kebohongan maupun kesombongan. Materi dongeng yang semacam ini dan bila diberikan secara terus menerus dan dalam suasana yang menyenangkan lambat laun akan tertanam pada diri anak untuk 
akhirnya dimiliki. Anak-anak akan belajar bahwa kebenaran adalah selalu menang dan keburukan atau kejahatan selalu kalah.

\section{Peranan Mendongeng dalam Menumbuhkan Minat Baca Anak}

Harus diakui bahwa kegiatan mendongeng akhir-akhir ini sudah jarang dilakukan orang. Kegiatan mendongeng dianggap kurang menarik untuk dilakoni oleh para orangtua karena bahan materi dongeng sulit didapat atau kesibukan orangtua dalam memenuhi keperluan keluarga maupun pendongeng kurang mampu membawa bahwa dongeng adalah cerita yang patut didengar, dihayati bahkan diamalkan. Tradisi bercerita/mendongeng lisa tidak bias menghindar dari persaingan budaya modern sehingga kegiatan bercerita/mendongeng sedikit demi sedikit terkikis oleh kemajuan teknologi.

Padahal, dongeng yang disampaikan dengan penuh rasa kasih sayang oleh orangtua kepada anak-anak, ternyata merupakan unsur penting bagi pertumbuhan jiwa anak-anak. Imajinasi yang begitu kaya dapat hadir di benak anak-anak, dan kemudian berperan positif bagi perkembangan kepribadian anak kelak.

Menurut Araby Ahmat dalam Artana (1997) mengemukakan bahwa dongeng bermanfaat untuk menanamkan pendidikan terhadap anak, seperti (1) mengarahkan agar anak hormat kepada orangtua, (2) mengarahkan anak agar menjadi orang yang taat beragama, (3) mengarahkan anak agar tidak melakukan perbuatan yang merusak masyarakat dan lingkungan, (4) mengarahkan anak menghargai jasa orang yang berbuaty kebajikan, (5) menanamkan sifat gotong royong pada anak, (6) berani menunjukkan kesalahan orang lain, dan (7) mampu menilai tingkah laku social masyarakat.

Keberhasilan suatu dongeng tidak saja ditentukan oleh daya rangsang imajinatifnya, tapi juga kesadaran dan kemampuan pendongeng untuk menyajikannya secara menarik. Menurut Kak Agam, seorang pendongeng yang tidak asing di kalangan anak-anak menyatakan bahwa manfaat dongeng untuk anak, antara lain : (1) mengasah daya pikir dan imajinasi, (2) menanamkan berbagi nilai dan etika, dan (3) menumbuhkan minat baca.

Membacakan cerita atau dongeng sebelum anak tidur, ternyata juga mampu menstimulasi anak untuk gemar dan bahkan menumbuhkan hobi 
membaca. Anak yang seringkali diperkenalkan dengan buku bacaan, juga diprediksi bakal lebih cepat untuk bisa lancar membaca. Menurut Satria Dharma, seorang konsultan Budaya Literasi dari Kemendikbud (Selasa, 31 Mei 2016) mengatakan "Mendongeng cerita apa saja, membuat anak suka mendengarkan dan akhirnya mengikuti orangtua untuk membaca," Mendongeng juga membantu perkembangan psikologis dan kecerdasan emosional anak, serta beberapa manfaat lain, seperti yang disampaikan oleh Efine, seorang psikolog sekaligus pendongeng, yaitu sebagai berikut.

a. Mengembangkan Imajinasi Anak

Dunia yang penuh imajinasi. Menurut Efnie, anak usia 3-7 tahun memiliki "dunia"-nya sendiri, bahkan mempunyai teman khayalan sebagai teman mereka bermain. Hal ini sebenarnya tidak salah, karena bisa membantu proses perkembangan mereka. Namun, sebaiknya orangtua tetap mengontrol imajinasi meeka agar tetap positif, salah satunya melalui pembacaan dongeng. Melalui dongeng yang dibacakan sang ibu, imajinasi anak akan diarahkan dengan lebih baik.

\section{b. Meningkatkan Keterampilan Berbahasa}

Mendengarkan dongeng merupakan salah satu stimulasi dini yang bisa digunakan untuk merangsang keterampilan berbahasa pada anak. Menurut penelitian, anak perempuan lebih cepat menguasai kemampuan berbahasa dibandingkan anak laki-laki. Hal ini disebabkan karena anak perempuan memiliki fokus dan konsentrasi yang lebih baik daripada laki-laki.

\section{c. Meningkatkan Minat Baca Anak}

Secara tak langsung, anak-anak yang memiliki ketertarikan pada dongeng akan memiliki rasa penasaran yang lebih tinggi. Cara yang paling mudah untuk mendongeng adalah dengan membacakan buku cerita kepada mereka. Ketika tertarik pada dongeng, mereka menjadi lebih tertarik pada buku-buku cerita bergambar. Dengan sendirinya, minat baca mereka juga meningkat. 


\section{d. Membangun Kecerdasan Emosional}

Selain mendekatkan keakraban ibu dan anak, mendongeng ternyata bisa membangun kecerdasan emosional anak. Anak-anak akan belajar tentang nilainilai moral dalam kehidupan. "Anak-anak kecil sulit untuk belajar tentang berbagai hal yang abstrak, seperti kebaikan pada sesama. Tetapi dengan dongeng, anak akan terbantu dalam memahami nilai-nilai emosional pada sesama," bebernya. Ditambahkan Efnie, anak-anak sekarang ini kebanyakan hanya memiliki kepandaian kognitif saja, padahal kepandaian emosional juga dibutuhkan untuk bersosialisasi dan berbuat baik pada sesama sebagai bekal kehidupan mereka.

\section{e. Membentuk Anak yang Mampu Berempati}

Stimulasi melalui dongeng akan mampu merangsang kepekaan anak usia 3-7 tahun terhadap berbagai situasi sosial. Mereka akan belajar untuk lebih berempati pada lingkungan sekitarnya. Stimulasi akan lebih baik jika dilakukan dengan merangsang indera pendengaran dibandingkan visual. Stimulasi visual melalui televisi atau game memang akan merangsang kepandaian visual, namun tidak akan merangsang kepekaan perasaan dan empati anak. Dengan pendengaran, dan cerita-cerita yang mendidik, anak akan lebih mudah menyerap nilai-nilai positif dan berempati dengan orang lain.

Selain itu, kegiatan mendongeng juga merupakan salah satu menumbuhkan minat baca pada diri anak-anak. Orangtua atau kanggota keluarga lainnya dapat berperan sebagai penutur dari buku-buku yang dibacanya dan sudah barang tentu materi dongeng disesuaikan dengan tingkat perkembangan bahasa dan usia anak.

Kegiatan mendongeng akan lebih efektif bilamana disampaikan atau diceritakan pada saat menjelang tidur, pada saat-saat santai kumpul keluarga, atau dapat juga diberikan menjelang dan sesudah pelajaran di kelas. Pembacaan dongeng harus dilakukan sedemikan rupa sehingga anak-anak tersedot ke dalam cerita tersebut. Bila kegiatan tersebut dilakukan secara baik, terus menerus, lambat laun akan timbul keinginan anak untuk membaca sendiri buku-buku tersebut. 
Bilamana kegiatan membaca sudah mulai tumbuh dan dilakukan semenjak dini, maka akan dapat berkembang menjadi kebiasaan hingga dewasa. Melalui membaca tidak hanya akan memperluas cakrawala ilmu dan pengetahuan, namun dapat pula mengasah daya nalar dan budi pekerti anak. Oleh karena menumbuhkan minat baca sangat penting dilakukan sejak usia dini.

Kegiatan apresiasi mendongeng seperti penyelenggaraan lomba mendongeng serta lomba bercerita (story telling) yang dilakukan oleh banyak pihak baik melalui jalur pendidikan formal maupun nonformal, nampaknya perlu ditindaklanjuti dan dikembangkan terus baik dari segi kuantitas maupun kualitasnya. Melalui kegiatan semacam itu di samping dapat mengarahkan anakanak untuk berani tampil untuk menceritakan apa yang telah dibacanya, juga dapat mengajak anak mengenali dan mencintai buku, yang pada akhirnya akan dapat terbentuk anak yang gemar membaca buku.

\section{PENUTUP}

\section{Simpulan}

Minat baca anak-anak saat ini belum menggembirakan. Peranan orangtua dan lembaga pendidikan sangat penting untuk menumbuhkan minat baca pada anak-anak. Untuk mewujudkannya diperlukan berbagai upaya agar anak-anak memiliki budaya gemar membaca. Salah satu upaya untuk menumbuhkan minat baca pada anak adalah dengan mendongeng.

Pada dasarnya dongeng mengandung nilai-nilai positif bagi kehidupan, karena didalamnya terkandung tuntutan moral dan etika. Kegiatan mendongeng (bercerita) merupakan salah satu upaya atau teknik untuk menumbuhkan minat baca pada diri anak-anak. Orangtua atau kanggota keluarga lainnya maupun pihak-pihak lain dapat berperan sebagai penutur dari buku-buku yang dibacanya dan sudah barang tentu materi dongeng disesuaikan dengan tingkat perkembangan bahasa dan usia anak.

Kegiatan mendongeng akan lebih efektif bilamana disampaikan atau diceritakan pada saat menjelang tidur, pada saat-saat santai kumpul keluarga, atau dapat juga diberikan menjelang dan sesudah pelajaran di kelas. Pembacaan dongeng harus dilakukan sedemikan rupa sehingga anak-anak tersedot ke dalam 
cerita tersebut. Bila kegiatan tersebut dilakukan secara baik, terus menerus, lambat laun akan timbul keinginan anak untuk membaca sendiri buku-buku tersebut.

\section{Daftar Pustaka}

Artana, I Ketut . 1997. Masih Pentingkah Kita Mendongeng. Artikel pada Singa Manggala Singaraja, Bali , Edisi Mg.III-IV Februari 1997

Artana, I Ketut. 1997. Mendidik Anak dengan Dongeng. Artikel pada Singa Manngala, Singaraja Bali, edisi Mg.III-IV Nopember 1997

Basuki, S. 1988. The Anatomy of Prose Fiction. Jakarta: Depdikbud, Dirjen Dikti

Dantes, Nyoman,dkk. 2016. Pengembangan Buku Dongeng Berbasis Budaya Lokal untuk Memfasilitasi Pembelajaran Tematik dalam rangka Optimalisasi Pendidikan Sikap dan Literasi Dini sesuai dengan Karakteristik Sioswa Kelas Awal SD. Laporan Akhir Penelitian Unggulan PT. Singaraja: Undiksha

Indonesia, 2007. Undang-Undang RI Nomor 43 Tahun 2007 tentang Perpustakaan. Jakarta: Perpustakaan Nasional RI

2014. Peraturan Pemerintah RI Nomor 24 Tahun 2014 tentang Pelaksanaan UU No.43 Tahun 2007 tentang Perpustakaan. Jakarta: Kemendikbud 